\title{
Competing Climate Change Responses: Reflections on EU Unilateral Regulation of International Transport Emissions in Light of Multilateral Developments
}

\author{
Natalie L. Dobson ${ }^{1}$ \\ Published online: 10 June 2020 \\ (c) The Author(s) 2020
}

\begin{abstract}
In 2016, the International Civil Aviation Organization (ICAO) and International Maritime Organization (IMO) made important strides towards the regulation of emissions from international aviation and maritime transport. This was partially catalysed by the 'ultimatum strategy' of the European Union (EU), where the Union persistently threatened to take unilateral steps in the absence of multilateral action. As this article analyses, it appears that the Union is reluctant to relinquish its unilateral approach and align fully with both the ICAO Carbon Offsetting and Reduction Scheme and the IMO Global Data Collection Scheme. This raises questions under public international law as to the relationships between these competing measures. Amidst rising political pressures, this article considers the extent to which the unfolding multilateral policies of the ICAO and IMO may limit the regulatory competence of the EU. While the EU is an independent legal entity, it has been conferred far-reaching competences by its Member States who are themselves members of these other international organisations. Given the lack of clarity on clear hierarchical rules, an important role remains for the customary law of state jurisdiction in governing regulatory competence more generally. The final part of this article engages with recent discussions on the existence of an obligation to exercise jurisdictional self-restraint. It reflects on the tensions arising between respect for states' regulatory autonomy and the prevention of 'dangerous' anthropogenic climate change.
\end{abstract}

Keywords Climate change $\cdot$ EU $\cdot$ Aviation · Maritime transport · Unilateralism · Emissions $\cdot$ Jurisdiction $\cdot$ Reasonableness

Natalie L. Dobson

n.1.dobson@uu.nl

1 Utrecht Centre for Water, Oceans and Sustainability Law, Utrecht University School of Law, Utrecht, The Netherlands 


\section{Introduction}

While greenhouse gas (GHG) emissions from international aviation and maritime transport are steadily on the rise, the ambition of multilateral responses was for a long time quite stagnant. ${ }^{1}$ The slow pace of multilateral responses has long been a source of frustration for the European Union (EU), that over the past years has responded with consistent steps towards its own unilateral emission reduction policy. ${ }^{2}$ Matters changed dramatically however, when both the International Civil Aviation Organization (ICAO) and International Maritime Organization (IMO) took considerable strides towards multilateral emission reduction responses. This came to a head in 2016, with the ICAO agreeing on a Carbon Offsetting and Reduction Scheme for International Aviation (CORSIA), ${ }^{3}$ while the IMO adopted a Global Data Collection Scheme (DCS) for international shipping emissions. ${ }^{4}$

Despite its nominal support for these agreements, the EU continues to express concern as to their ambition. Thus at a 2019 climate summit it noted that the current global targets and measures envisaged' by the IMO and ICAO 'even if implemented in full, would fall short of the necessary emissions reductions' for the EU's goal of decarbonisation by $2050 .^{5}$ In view of this, the Union is consistently refusing to align its standards with those of the ICAO and IMO. Multilateral and unilateral measures are therefore starting to occupy the same regulatory space, with the possibility of further divergence in the future. Indeed, matters are already heating up. At the time of writing, as of 1 January 2021, international offset credits, including those 'deemed to be eligible' under CORSIA will not be recognised under the EU Emissions Trading Scheme (ETS). ${ }^{6}$ Conversely, in a resolution of late 2019, the ICAO adopted an 'exclusivity clause', 'determining' the CORSIA to be 'the only global market-based measure applying to $\mathrm{CO}_{2}$ emissions from international aviation'.

\footnotetext{
1 See, IMO Resolution MEPC.304(72), 'Initial IMO Strategy on Reduction of GHG Emissions from Ships' (adopted 13 April 2018), MEPC 72/17/Add.1 (hereinafter: IMO Initial Reduction Strategy), para. 1.6 noting that maritime emissions are projected to increase by $50-250 \%$ by 2050 compared to 2012 levels. See regarding aviation, Carbon Brief (2018).

2 Parliament and Council (EC) Decision 1600/2002/EC of 22 July 2002 laying down the Sixth Community Environment Action Programme [2002] OJ L 242/1 (hereinafter: EU 6th EAP).

3 See further on the EU's strategy, Scott and Rajamani (2012) and Boisson de Chazournez (2000).

4 ICAO Resolution A39-3, 'Consolidated statement of continuing ICAO policies and practices related to environmental protection-Global Market-based Measure (MBM) scheme' (adopted 39th Session of the ICAO Assembly, 27 September-6 October 2016) (hereinafter: CORSIA); and IMO Data Collections Scheme adopted in IMO Resolution MEPC.278(70), 'Amendments to the Annex of the Protocol of 1997 to amend the International Convention for the Prevention of Pollution from Ships, 1973, as modified by the Protocol of 1978 relating thereto-Data Collection System for Fuel Oil Consumption of Ships' (adopted 28 October 2016), MEPC 70/18/Add.1, Regulation 22A, 'Collection and reporting of ship fuel oil consumption data' (hereinafter: IMO MEPC.278(70)).

5 European Parliament resolution of 28 November 2019 on the 2019 UN Climate Change Conference in Madrid, Spain (COP 25) (2019/2712(RSP)) (hereinafter: EP Resolution COP 25), para. 70.

6 See further, https://ec.europa.eu/transport/sites/transport/files/2019-aviation-environmental-report.pdf.

7 Emphasis added. ICAO Resolution A40-19, 'Consolidated statement of continuing ICAO policies and practices related to environmental protection-Carbon Offsetting and Reduction Scheme for International Aviation (CORSIA)' (adopted 40th Session of the ICAO Assembly, 24 September-4 October 2019), para. 18. See also, Morgan (2019).
} 
Against the backdrop of these policy developments, this article will analyse the relationships between these competing climate change responses under public international law. In light of the unique nature of the EU as a supranational actor, Sect. 2 will first set out the theoretical framework for the present analysis of the Union's collective unilateral action. Section 3 then turns to the concrete elements of the EU's 'ultimatum strategy', used here to describe the EU's threats and use of unilateral acts as a means of catalysing and steering multilateral action. It will consider the emerging divergencies between multilateral and EU unilateral measures. Section 4 proceeds to analyse the extent to which the current multilateral standards may condition the EU's unilateral regulatory competence. Notably, it does not conduct a full compatibility analysis of the EU measures with all of the applicable rules. Section 4.1 focuses on the debated relationship between the EU and the Chicago Convention on International Civil Aviation (Chicago Convention) and the CORSIA rules in Annex 16. ${ }^{8}$ Section 4.2 then examines the extent to which the EU may have a duty to align with the IMO DCS in Annex VI of the International Convention for the Prevention of Pollution from Ships (MARPOL). ${ }^{9}$

Supplementing these fields is the customary law of state jurisdiction, which governs state competence to regulate the conduct and consequences of an event. ${ }^{10}$ Section 5 explores these more general jurisdictional rules on the apportioning of regulatory competence. Of particular relevance is the scholarly debate on jurisdictional 'reasonableness' and interest-balancing in light of the new position taken in the 2018 Restatement (Fourth) of US Foreign Relations Law. ${ }^{11}$ It also considers the underlying normative question as to the desirable relationship between the ends and the means, particularly in light of the objective in the United Nations Framework Convention on Climate Change (UNFCCC) and Paris Agreement of preventing 'dangerous' climate change, by keeping global warming 'well below' $2{ }^{\circ} \mathrm{C}$. ${ }^{12}$

\footnotetext{
${ }^{8}$ Chicago Convention on International Civil Aviation (adopted 7 December 1944, entered into force 4 April 1947), 15 UNTS 295 (hereinafter: Chicago Convention); First Edition of Annex 16, Environmental Protection, Volume IV 'Carbon Offsetting and Reduction Scheme for International Aviation (CORSIA)' (adopted by the ICAO Council on 27 June 2018) (hereinafter: CORSIA SARPs).

9 The International Convention for the Prevention of Pollution from Ships, signed in London on 2 November 1973, as supplemented by the Protocol of 17 February 1978 (hereinafter: MARPOL); The Protocol of 1997 amending the International Convention of 1973 for the Prevention of Pollution from Ships, as amended by the Protocol of 1978 relating thereto, signed in London on 26 September 1997 added Annex VI, 'Prevention of Air Pollution from Ships'.

10 Jennings and Watts (1992), p. 456.

11 Restatement (Fourth) of the Foreign Relations Law of the United States (Am Law Inst 2018) (hereinafter: US Fourth Restatement).

12 United Nations Framework Convention on Climate Change (adopted 9 May 1992, entered into force 21 March 1994), 1771 UNTS 107 (hereinafter: UNFCCC), Art. 2; Paris Agreement to the United Nations Framework Convention on Climate Change (adopted 22 April 2016, entered into force 4 November 2016) (hereinafter: Paris Agreement), Art. 2(1)a.
} 


\section{Theoretical Framework: EU (Collective) Unilateralism from an International Law Perspective}

While the EU claims considerable autonomy to adopt unilateral standards, in reality it operates in what Wessel has termed a 'global normative web', where 'many of its positions and decisions are closely connected to policies and decisions of other international bodies'. ${ }^{13}$ The question of the EU's relationship with the international legal order is then a highly contentious one, a detailed analysis of which goes beyond the scope of this article. At its core, as noted by Ziegler, much turns upon whether one conceives of the EU 'as a creature of international law' or rather 'as sui generis because of its advanced constitutionalisation'. ${ }^{14}$ This article takes a moderate international law perspective, conceiving of the EU as an international organisation, based on multilateral constituent treaties, and endowed with legal personality by virtue of the conferral of sovereignty from its Member States. ${ }^{15}$ At the same time, one cannot ignore the far-reaching supranational competences of the EU institutions, and the highly-evolved and integrated nature of the EU legal order. As such, the relationships between the decisions of the various actors cannot be fully understood without some consideration of the EU law perspective on its position in the international legal order. ${ }^{16}$

The present enquiry is further premised upon a neutral approach to 'unilateral acts', as neither lawful or unlawful per se. ${ }^{17}$ These are defined as acts 'formulated by a State with the intent of producing certain legal effects under international law'. ${ }^{18}$ The core characteristic of a unilateral act is that it is taken without recourse to international procedure. ${ }^{19}$ Such acts are an exercise of state sovereignty, and will only be illegal when there are restrictions in international law. ${ }^{20}$ Notably, the EU is considered to exercise 'collective unilateralism', as it is a group of states acting together as a single legal person. ${ }^{21}$ Despite this neutral conceptualisation, as noted by Sands, unilateralism remains a 'term of art', 'because the territorial limits to the exercise of sovereign autonomy remain in a state of flux, and because the standards set by international law remain incomplete in many areas and ambiguous and open-textured in many others'. ${ }^{22}$ As will be seen, this statement made in 2000 could not be more true twenty years later, in the context of the EU climate-protective measures.

\footnotetext{
13 Wessel and Odermatt (2018), p. 7.

14 Ziegler (2015), p. 1.

15 These are the EU primary treaties, the Treaty on European Union [2012] OJ C 326/01 (hereinafter TEU); and the Treaty on the Functioning of the European Union [2012] OJ C 326/47 (hereinafter: TFEU). Ziegler (2015), p. 3 described the EU as having as 'derived' legal personality (codified in Art. 47 TEU).

16 See for a comprehensive analysis, Eeckhout (2011).

17 See further on unilateralism as a 'passe-partout', Boisson de Chazournez (2000), p. 316. See further, Bodansky (2000), p. 339.

18 Nollkaemper (2011), para. 2, citing Nuclear Tests (Australia v. France) [1974] ICJ Rep. 253.

19 Hakimi (2014), p. 111.

20 This reflects the finding in Island of Palmas (Netherlands v. United States) [1928] 2 RIAA 829, where it was famously found that restrictions upon sovereignty 'cannot be presumed' (p. 839).

21 Dupuy (2000), p. 20.

22 Sands (2000), p. 293.
} 
Evidently, as noted by the International Court of Justice (ICJ), international organisations 'are subjects of international law and, as such, are bound by any obligations incumbent upon them under general rules of international law'. ${ }^{23}$ However, determining which obligations are 'incumbent' upon the EU is not a straightforward exercise. $^{24}$ The EU is a party to the UNFCCC and the 1998 Kyoto Protocol, Article 2(2) of which designates the ICAO and IMO as the fora within which Annex I Parties to the UNFCCC 'shall pursue' the reduction of greenhouse gases from aviation and marine bunker fuels. ${ }^{25}$ At the same time, international transport emissions were excluded from the scope of states' mandatory reduction commitments, with the 2015 Paris Agreement remaining silent on this issue. Arguments have been made that Article 2(2) of the Kyoto Protocol provides for a 'transfer of responsibilities' to these specialised organisations, which-at least once exercised-exclude concurrent unilateral measures. ${ }^{26}$ This contribution follows the opposing view that does not read the Kyoto Protocol as excluding parties' parallel competence. ${ }^{27}$ Such exclusivity does not appear supported by the text or by the broader context of the agreement which encourages individual reduction policies more generally.

Determining the relationship between the IMO, ICAO and EU measures thus requires further unpacking. As it is not a state, the Union is not a full member of the ICAO and the IMO. The EU is also not a formal party to the 1958 Chicago Convention, with its recent CORSIA amendment to Annex 16. It is further not a party to the MARPOL and its Annex VI, which was amended to contain the IMO DCS. As will be discussed, for its part, EU law does not particularly support systemic coherence, employing a very restrictive interpretation of when the Union may itself be bound by obligations incumbent upon all of its Member States. ${ }^{28}$

What results is a 'conflict' of norms in the broader sense, defined here as 'a situation where two rules or principles suggest different ways of dealing with a problem'. ${ }^{29}$ There is a considerable group affected by the competing regulatory frameworks, as the EU measures seek to regulate conduct and circumstances beyond its territory. This gives rise to issues of state jurisdiction under customary international

\footnotetext{
${ }^{23}$ Interpretation of the Agreement of 25 March 1951 between the WHO and Egypt, Advisory Opinion [1980] ICJ Rep. 73, p. 90.

24 See for a broader analysis, Daugirdas (2016), p. 333.

25 Kyoto Protocol to the United Nations Framework Convention on Climate Change (adopted 11 December 1997, entered into force 16 February 2005), UN Doc. FCCC/CP/1997/7/Add.1, 10 December 1997 (hereinafter: Kyoto Protocol), Art. 2(2), referring to aviation 'not controlled by the Montreal Protocol'.

26 See e.g. Erling (2018).

27 See further in support e.g. Martinez Romera (2016), p. 217; Bäuerle (2012), p. 119, referring to arguments of Advocate General Kokott in Case C-366/10, Air Transport Association of America, American Airlines, Inc, Continental Airlines, Inc, United Airlines, Inc v. The Secretary of State for Energy and Climate Change [2011] ECR I-13755 (hereinafter: ATAA case).

28 This refers to the doctrine of functional succession under EU law, first accepted in Joined Cases 21 to 24/72 International Fruit Company v. Produktschap voor Groenten en Fruit [1972] ECR 01219 (hereinafter: International Fruit). This is discussed further in Sect. 4.

29 International Law Commission, 'Fragmentation of International Law: Difficulties Arising from the Diversification and Expansion of International Law', Report of the Study Group of the International Law Commission (13 April 2006), A/CN.4/L.682 (hereinafter: ILC Report on Fragmentation), para. 25, discussed in the context of climate change by van Asselt (2007), p. 3.
} 
law. Notably, there is heated discussion as to whether customary international law binds international organisations generally, particularly given their limited-if at all-contribution to its formation. ${ }^{30}$ This relates to the broader debate on whether being a subject of international law with separate legal personality entails that 'general rules' - itself a contested category — are necessarily binding. ${ }^{31}$ In this regard, Reinisch appealingly argues that if the functionally limited personality of international organizations develops over time [...] they are in fact subject to [custom] when they act in a way capable of infringing it'. ${ }^{32}$ This aligns with 'the legal premise that "subjects of international law" are usually "subject to international law". 33 For its part, the Court of Justice of the European Union (CJEU) has unequivocally recognised that custom binds the EU, and has indeed applied customary jurisdictional rules. ${ }^{34}$ In light of the forgoing, and the fact that the customary rules are binding upon all of the EU Member States, custom is considered here as being very relevant to the delimitation of EU jurisdictional competences.

Before examining these issues in more detail, Sect. 3 will now consider the concrete points of tension arising from the EU's 'ultimatum strategy', particularly since the conclusion of multilateral agreements in 2016.

\section{The EU's Persistent 'Ultimatum Strategy' in the Field of Aviation and Maritime Transport}

The EU's unilateral approach to aviation and maritime emissions has long been a subject of contention. Its 2002 Sixth Community Environment Action Programme (6th EAP) noted the 'priority action' of 'identifying and undertaking specific actions to reduce greenhouse gas emissions from aviation if no such action is agreed within the International Civil Aviation Organisation by 2002'. ${ }^{35}$ Along parallel lines, the Union was required to identify and undertake 'specific actions' for the reduction of emissions from marine shipping, 'if no such action is agreed within the International Maritime Organisation by 2003, ${ }^{36}$ This was notably part of a two-stranded approach, the EU alternatively lobbying for the inclusion of transport emissions in the new agreement to be negotiated under UNFCCC. ${ }^{37}$

Over the subsequent years, the EU steadily increased the pressure on the international community through threats and consecutive steps of unilateral action that

\footnotetext{
30 See e.g., Schermers and Blokker (2011), p. 1004; Klabbers (2017), p. 997; Daugirdas (2016), p. 325.

31 Klabbers (2017), pp. 998-999, argues that 'general rules' refers to secondary rules and not to custom and general principles. See for an opposing view, Reinisch (2017), pp. 1016-1019.

32 Reinisch (2017), p. 1021.

33 Ibid., p. 1019.

${ }^{34}$ Case C-162/96 Racke v. Hauptzollamt Mainz [1998] ECR I-3655, paras. 45-56; ATAA case, above n. 27, para. 101.

35 EU 6th EAP, above n. 2, para. 5(2)(iii)a.

36 Ibid.

37 See e.g. Parliament and Council (EC) Decision 406/2009 on the effort of Member States to reduce their greenhouse gas emissions to meet the Community's greenhouse gas emission reduction commitments up to 2020 [2009] OJ L 140/136, rec. 2.
} 
would include operators beyond its territory. ${ }^{38}$ This is referred to here as the EU's 'ultimatum strategy'. Sections 3.1 and 3.2 will briefly outline the relevant policy background and state of play for aviation and maritime emissions respectively. Despite the EU's nominal prioritisation of multilateralism, ${ }^{39}$ it is shown that the EU's 'ultimatum strategy' has now shifted its objective from achieving the conclusion of multilateral agreements, to increasing the level of ambition and environmental integrity envisioned in their design. According to the EU, this is necessary in order for it to achieve its $40 \%$ reduction commitment under the Paris Agreement, to which 'all sectors of the economy must contribute'. ${ }^{40}$

\subsection{The EU Emission Trading Scheme and the ICAO CORSIA}

Turning first to aviation, the EU's unilateral approach is well-known and quite controversial. After years of threats, the EU adopted the Aviation Directive, which extended the EU's ETS to cover international aviation emissions for flights to and from EU territory as of 2012. ${ }^{41}$ Push-back from industry led to the Air Transport Association of America (ATAA) case before the CJEU. ${ }^{42}$ There the EU was accused, among other things, of violating the Chicago Convention and overstepping its jurisdiction. For its part, the CJEU did not find that the extended ETS violated international law. ${ }^{43}$ However, threats of economic sanctions from other states pressured the EU to restrict the scope of the Aviation Directive to flights within the European

\footnotetext{
38 See further Scott (2014), p. 107, noting that the EU 'uses territorial extension both to prompt the emergence of international (bilateral or multilateral) agreements'.

39 Indeed, the EU Strategic Agenda for 2019-2024 puts multilateralism at the forefront, stating that the 'EU will remain a driving force behind multilateralism and the global rules-based international order', 'support[ing] the UN and key multilateral organisations'. European Council, A New Strategic Agenda 2019-2014 (2019), available at: https://www.consilium.europa.eu/media/39914/a-new-strategic-agend a-2019-2024.pdf (accessed 15 September 2019).

40 Latvian Presidency of the Council of the European Union (6 March 2015), 'Submission by Latvia and the European Commission on behalf of the European Union and its Member States: Intended Nationally Determined Contribution of the EU and its Member States', available at: https://ec.europa.eu/clima /sites/clima/files/docs/2015030601_eu_indc_en.pdf (accessed 17 September 2019). See on the inclusion of intra-EU aviation in this target, Commission Delegated Regulation (EU) 'supplementing Directive 2003/87/EC of the European Parliament and of the Council as regards measures adopted by the International Civil Aviation Organisation for the monitoring, reporting and verification of aviation emissions for the purpose of implementing a global market-based measure', C(2019) 1644 final, 6 March 2019 (hereinafter: Delegated Regulation regarding ICAO MRV measures), p. 2.

41 Parliament and Council (EC) Directive 2008/101 amending Directive 2003/87/EC so as to include aviation activities in the scheme for greenhouse gas emission allowance trading within the Community [2008] OJ L 8/3 (hereinafter: Aviation Directive); Parliament and Council (EU) Directive 2003/87/EC establishing a scheme for greenhouse gas emission allowance trading within the Community and amending Council Directive 96/61/EC [2003] OJ L 275 (hereinafter: EU ETS).

${ }^{42}$ ATAA case, above n. 27.

43 Ibid., paras. 61 and 124.
} 
Economic Area (EEA). ${ }^{44}$ This was notably a temporary move, considered 'desirable', 'in order to sustain the momentum' of ICAO negotiations of a single global market-based measure for international aviation emissions. ${ }^{45}$

In late 2016, the ICAO reached an agreement on an offsetting scheme in the form of the CORSIA. ${ }^{46}$ Seeking to take into account parties' 'special circumstances and respective capabilities', the CORSIA has a 'phased' and 'routes-based' approach, with base year 2019-2020. ${ }^{47}$ Participation in the 'pilot phase' from 2021-2023, and the 'first phase' from 2024-2026, is voluntary. ${ }^{48}$ It is only during the second phase from 2027-2035 that states whose share in the total international revenue tonnes per kilometre (RTK) is above a certain threshold are obliged to participate. ${ }^{49}$ As noted by Erling, the 'most distinct feature' of such an offset scheme is that overall emissions can grow without limits, as long as emissions are compensated by 'offset units' coming from different emission reduction projects in other industries. ${ }^{50}$ This differs fundamentally from the EU ETS, which sets a quantitative cap on emissions, allotting a set amount credits to be traded on the market.

Responding to international developments, the EU adopted Regulation 2017/2392, 'amending Directive 2003/87/EC to continue current limitations of scope for aviation activities and to prepare to implement a global market-based measure from 2021, ${ }^{51}$ While the title suggests an intention to align EU and ICAO measures, this has not proven to be entirely the case. Rather, the Commission is instructed to present a report considering ways to implement the 'relevant ICAO instruments' through a revision of the ETS. ${ }^{52}$ This report 'shall also examine the ambition and overall environmental integrity of the global market-based measure, including its general ambition in relation to targets under the Paris Agreement, the level of participation, its enforceability, transparency, [and] the penalties for noncompliance [...] ${ }^{53}$ Based on its assessment of these criteria, the Commission must provide a proposal to, 'where appropriate', 'amend, delete, extend or replace' the current derogations (Art. 28b(3) Aviation Directive). Importantly, this proposal

\footnotetext{
44 Parliament and Council Regulation (EU) 421/2014 amending Directive 2003/87/EC establishing a scheme for greenhouse gas emission allowance trading within the Community, in view of the implementation by 2020 of an international agreement applying a single global market-based measure to international aviation emissions [2014] OJ L 129/140, regulates the interim period (hereinafter: Regulation 421/2014), Art. 1. See for further analysis, Kulovesi (2011).

45 Regulation 421/2014, above n. 44, rec. 3.

46 CORSIA, above n. 4, para. 5.

47 Ibid., Art. 10(a). Under the 'routes-based' approach, aircraft operators are only subject to the scheme when the states of both landing and departure participate.

48 Ibid., Art. 9(a), (b).

49 Ibid., Art. 9(e). This applies to countries with an individual share of at least $0.5 \%$ of the total international revenue tonne kilometre (RTK) in 2018, and to states whose cumulative share in the list of states from the highest to the lowest amount of RTKs reaches $90 \%$ of the total RTKs.

50 Erling (2017), p. 5 (emphasis added). See also, Erling (2018).

51 Parliament and Council (EU) Regulation 2017/2392 of 13 December 2017 amending Directive 2003/87/EC to continue current limitations of scope for aviation activities and to prepare to implement a global market-based measure from 2021 [2017] OJ L 350/7 (hereinafter: Regulation 2017/2392).

52 Ibid., Art. 7 (emphasis added).

53 Ibid., inserting 28b(2) to the EU ETS, above n. 41.
} 
shall be 'consistent with the Union economy-wide greenhouse gas emission reduction commitment for 2030 with the aim of preserving the environmental integrity and effectiveness of Union climate action'. ${ }^{54}$ EU policy expressly states that in the absence of a new amendment, the EU ETS would revert back to its original full scope from 2024,55

In the meantime, some alignment is sought through amendments to the EU's existing Regulation on monitoring and reporting (MRR) and Regulation on verification and accreditation of verifiers (AVR). ${ }^{56}$ A further, more contentious measure is the Delegated Regulation 'supplementing' the Aviation Directive as regards the adopted ICAO MRV measures (Delegated Regulation regarding ICAO MRV measures). ${ }^{57}$ This delegated act 'complements' the existing EU measures in respect of flights and operations that are not currently covered by the EU ETS Directive'. ${ }^{58}$ The new Article 28c of the Aviation Directive requires that these measures be 'based on the relevant instruments adopted in the ICAO' and 'avoid any distortion of competition'. ${ }^{59}$ However, they must also be consistent with the EU's own monitoring and reporting principles and its verification requirements. ${ }^{60}$

Embedded in EU policy is thus a tension between alignment with ICAO standards and maintaining its desired level of environmental protection. At the time of writing, this is already leading to several divergencies between EU and ICAO measures. For example, the Implementing Regulation for the MRR only recognises two methods for the monitoring of fuel consumption, while the CORSIA SARPs recognise five. ${ }^{61}$ This poses a restriction on the newly included group of operators based in EEA outermost regions or dependencies and territories of EU Member States. ${ }^{62}$

\footnotetext{
54 Ibid., inserting 28b(3) to the EU ETS, above n. 41, See further comparing ICAO and EU targets, van Velzen (2018), p. 5.

55 Statement on the Commission website, available at: https://ec.europa.eu/clima/policies/transport/aviat ion_en (accessed 28 November 2019).

56 Commission Implementing Regulation (EU) 2018/2066 of 19 December 2018 on the monitoring and reporting of greenhouse gas emissions pursuant to Directive 2003/87/EC of the European Parliament and of the Council and amending Commission Regulation (EU) No. 601/2012 [2018] OJ L 334/1; Commission Implementing Regulation (EU) 2018/2067 of 19 December 2018 on the verification of data and on the accreditation of verifiers pursuant to Directive 2003/87/EC of the European Parliament and of the Council [2018] OJ L 334/94 (hereinafter: Commission AVR Implementing Regulation).

57 Delegated Regulation regarding ICAO MRV measures, above n. 40.

58 Explanatory Memorandum to the Delegated Regulation regarding ICAO MRV measures above n. 40, p. 2 (emphasis added).

59 Regulation 2017/2392, above n. 51, Art. 7.

60 Ibid.

61 The EU recognises 'Method A' or 'Method B' only. See Commission Regulation (EU) 601/2012 of 21 June 2012 on the monitoring and reporting of greenhouse gas emissions pursuant to Directive 2003/87/EC of the European Parliament and of the Council [2012] L 181/30 (hereinafter: EU MRR), as amended, Art. 52 of which refers to the methods laid down in Section 1 of Annex III. This is maintained for the period after 2021. Compare with the CORSIA SARPs, above n. 8, Appendix 2. See for critique, IATA (2019), arguing that three additional fuel monitoring methods, not only provide more flexibility, but are also argued to be simpler in execution.

62 Regulation 421/2014, above n. 44. Operators must also report emissions from flights between the EU and 'outermost regions, dependencies or territories of other Member States' (Delegated Regulation regarding ICAO MRV measures, above n. 40, Art. 2(2)).
} 
Furthermore, the EU MRV requirements do not foresee in the simplified CORSIA ' $\mathrm{CO}_{2}$ Estimation and Reporting Tool' (CERT) for small scale operators. ${ }^{63}$ The EU notably has its own Small Emitters Tool (SET), however this is only open to a more restricted group. ${ }^{64}$ As regards verification, the EU measures require verifier accreditation by a 'national accreditation body', of which each EU Member State has one. ${ }^{65}$ Under CORSIA, 'verification bodies' are defined more broadly as an 'accredited independent third party'. ${ }^{66}$ These bodies could be accredited by any CORSIA member, not just an EU Member State. ${ }^{67}$

Furthermore, in terms of scope, the categories exempted from MRV requirements under the EU and ICAO measures do not match entirely. ${ }^{68}$ For example "scientific research and testing' is exempt under the EU measures but not the CORSIA. Interestingly, under the EU Delegated Regulation, covered aircraft operators are only 'recommended' but not obliged to verify and report emissions from flights between two third countries (Art. 2(3)). This contrasts with the CORSIA SARPs which for operators from participating countries are applicable to 'all international flights' on or after January $2019 .{ }^{69}$ The EU's rationale, however, is largely based on doubts as to the jurisdiction of the Commission to regulate these 'extraterritorial' flights. ${ }^{70}$

The above comparison illustrates that the EU is already maintaining a stricter standard at the stage of MRV requirements. Responding to the emerging divergencies, in late 2019 ICAO Resolution 40-19 was adopted, providing that 'the CORSIA is the only global market-based measure applying to $\mathrm{CO}_{2}$ emissions from international aviation. ${ }^{71}$ The aim of this move is 'to avoid a possible patchwork of duplicative State or regional MBMs [market-based measures]'. ${ }^{72}$ Intriguingly, despite calls from both the European Parliament and the Commission, none of the EU Member

\footnotetext{
63 The CERT may be used by operators with annual emissions below 500,000 tonnes in the year 20192020, see CORSIA SARPs, above n. 8, chap. 2.2.2.

64 The Eurocontrol SET may be used by emitters of less than 25,000 tonnes of $\mathrm{CO}_{2}$ per year (or annually flying less than 243 flights per consecutive four month period). See, EU MRR, above n. 61, Art. 54.

65 Commission AVR Implementing Regulation, above n. 56, Art. 44 and Art. 55(1): 'The tasks related to accreditation pursuant to this Regulation shall be carried out by the national accreditation bodies appointed pursuant to Article 4(1) of Regulation (EC) No 765/2008'. Art. 4(1) of Regulation No. 765/2008 states that: 'Each Member State shall appoint a single national accreditation body'.

66 CORSIA SARPs, above n. 8, chap. 2.4.1.1 referring to definitions in chap. 1.

67 Commission AVR Implementing Regulation, above n. 56. Art. 56 does foresee in the possibility 'cross-border accreditation', where an EU Member State considers it 'economically not meaningful or sustainable' to establish its own accreditation body. Still, this is limited to EU Member States.

68 Art. 2(4) of the Delegated Regulation regarding ICAO MRV measures, above n. 40, exempts aircraft operators from reporting emissions from flights 'for the purposes of training or search and rescue', 'for scientific research and testing' and 'Public Service Obligation flights'. The CORSIA SARPs does not exempt these categories, but does exempt humanitarian, medical and firefighting flights.

${ }^{69}$ CORSIA SARPs, above n. 8, chap. 2.1.1, applicable to 'international flights' as defined in chap. 1.1.2 as 'the operation of an aircraft from take-off at the aerodrome of State or its territories, and landing at an aerodrome of another State or its territories'.

${ }^{70}$ In a 2019 explanatory memorandum the Commission noted that 'whether greater powers would be appropriate' should be further examined See further Explanatory Memorandum to the Delegated Regulation regarding ICAO MRV measures, above n. 40, p. 4, explaining Art. 2, para. 3.

71 ICAO Resolution A40-19, above n. 7, para. 18.

72 Ibid., para. 18.
} 
States made a formal reservation to the exclusivity clause. ${ }^{73}$ Taken together, interesting questions thus arise for the legal relationship between these overlapping measures, considered further in Sect. 4.

\subsection{The EU Maritime MRV Scheme and the IMO DCS}

Closely following the aviation sector, the EU's ultimatum strategy has clearly manifested itself in the field of international shipping. By mid-2013 the Commission was clear that the 'deadline has passed without sufficient international action' on maritime emission reductions. ${ }^{74}$ It therefore proposed a regulation introducing a monitoring, reporting and verification scheme for maritime transport as a 'first step' towards inclusion in the EU emission reduction target. ${ }^{75}$ This was realised in Regulation 2015/757 (EU Maritime MRV), under which operators of ships above 5000 gross tonnes are obliged to monitor, by means of the fuel consumed, the amount of $\mathrm{CO}_{2}$ emitted on voyages to and from EEA ports. ${ }^{76}$ Swiftly after, in 2016 , the IMO Marine Environmental Protection Committee (MEPC) adopted its own mandatory global data collection scheme (DCS) for $\mathrm{CO}_{2}$ emissions as an amendment to Annex VI of MARPOL. ${ }^{77}$ As of 1 January 2019, the IMO DCS obliges ships above 5,000 gross tonnes to monitor and report fuel consumption to their Administration (flag state). ${ }^{78}$

As with civil aviation, the IMO and EU measures do not mirror each other. ${ }^{79}$ Article 22(3) of the EU Maritime MRV is said to have 'anticipated' this situation, instructing the Commission to 'review this Regulation' and, 'if appropriate, propose amendments [...] in order to ensure alignment with that international agreement ${ }^{80}$ However, the Commission's Proposal for a Regulation amending the Maritime MRV to 'take appropriate account of global data collection system', already

\footnotetext{
73 See for consideration of future options, Rothenberg (2019).

74 This was notably despite the IMO's adoption in 2011 of amendments to Annex VI of the International Convention for the Prevention of Pollution from Ships (MARPOL) for the prevention of air pollution (the Energy Efficiency Design Index (EEDI) and the Ship Energy Efficiency Management Plan (SEEMP)), the EU considered that 'further action needs to be taken'. Commission (EU), 'Integrating maritime transport emissions in the EU's greenhouse gas reduction policies', (Communication) COM(2013) 479 final, 28 June 2013 (hereinafter: $\operatorname{COM}(2013)$ 479), p. 4.

75 See further on the next steps considered, $\operatorname{COM}(2013) 479$, above n. 74, p. 4.

76 Parliament and Council (EU) Regulation 2015/757 on the monitoring, reporting and verification of carbon dioxide emissions from maritime transport, and amending Directive 2009/16/EC [2015] OJ L 123/55 (hereinafter: EU Maritime MRV).

77 IMO MEPC.278(70), above n. 4, adding a new 'Regulation 22A, Collection and reporting of ship fuel oil consumption data' to MARPOL, above n. 9, Annex VI.

78 IMO MEPC.278(70), above n. 4, Regulation 22A, para. 3.

79 For a comprehensive tabulated overview see Commission Staff Working Document, Impact Assessment Accompanying the document 'Proposal for a regulation of the European Parliament and of the Council amending Regulation (EU) 2015/757 in order to take appropriate account of the global data collection system for ship fuel oil consumption data', SWD(2019) 10 final, 4 February 2019 (hereinafter: Impact Assessment MRV Amendment), p. 15: 'Table 2.1. Comparison of EU MRV Regulation and IMO DCS features'.

80 Ibid., p. 5.
} 
rejects complete alignment. ${ }^{81}$ According to this proposal, 'the objective is not to replace the EU MRV Regulation by the IMO DCS' ${ }^{82}$ Rather, the 'main challenge' is 'to find appropriate ways to help market actors implement both schemes while streamlining and reducing administrative burden as possible, and while preserving the objectives of the EU MRV Regulation'. ${ }^{83}$ Interestingly, these objectives appear to be framed largely in terms of the contentious differences between the data collection measures. $^{84}$

To note some key examples, the EU Maritime MRV requires data on the actual load carried or $\mathrm{CO}_{2}$ emitted, while the IMO DCS focuses only on the fuel consumed during a ship's voyage. ${ }^{85}$ The EU Maritime MRV further includes domestic $\mathrm{CO}_{2}$ emissions-i.e. emissions from voyages within EU states, while the IMO DCS only covers fuel consumed on international voyages. ${ }^{86}$ The 2019 Impact Assessment accompanying the proposed regulation does not support further alignment, considering that this would undercut the required data for the design of "coherent and cost-effective climate, energy and environmental policies' ${ }^{87}$ In addition, the EU Maritime MRV requires the appointment of independent accredited verifiers. ${ }^{88}$ This differs from the IMO DCS, where verification of the monitoring and reporting activities is to be carried out by a ship's Administration according to national procedures. A 'departure' from third party accreditation was considered unacceptable for the EU, potentially harming the 'reliability' and 'accuracy' of the system. ${ }^{89}$

Another issue is that of transparency. Under the IMO scheme, the Secretary General of the IMO will produce an annual summary of the aggregated anonymised data to be presented to the MEPC. ${ }^{90}$ This differs from the EU Maritime MRV which requires the publication of information "with the aim of informing the public and allowing for an assessment of the $\mathrm{CO} 2$ emissions and the energy efficiency of maritime transport per size, type of ships, [and] activity'. ${ }^{91}$ This EU strategy has a potential naming and shaming effect, and is intended to 'incentivise the uptake' of energy efficiency measures by operators. ${ }^{92}$ The 2019 Impact Assessment considered that

\footnotetext{
81 Commission (EU), 'Proposal for a Regulation of the European Parliament and of the Council amending Regulation (EU) 2015/757 in order to take appropriate account of the global data collection system for ship fuel oil consumption data' (Communication) $\operatorname{COM}(2019) 38$ final, 4 February 2019 (hereinafter: $\operatorname{COM}(2019) 38)$.

82 Ibid., Explanatory Memorandum, p. 2 (emphasis added).

83 Ibid. (emphasis added).

84 Ibid., p. 2.

85 See EU Maritime MRV, above n. 76, Annexes I, II for the data required. See, IMO MEPC.278(70), above n. 4, Appendix IX for the 'Information to be Submitted to the IMO Fuel Oil Consumption Database'.

86 See for its scope, EU Maritime MRV, above n. 76, Art. 2(1).

87 Impact Assessment MRV Amendment, above n. 79, p. 26.

${ }^{88}$ IMO MEPC.278(70), above n. 4, Regulation 22A, para. 7. See for the EU approach, EU Maritime MRV, above n. 76, Art. 16.

89 Impact Assessment MRV Amendment, above n. 79, p. 30.

90 IMO MEPC.278(70), above n. 4, Regulation 22A, para. 11.

91 EU Maritime MRV, above n. 76, Art. 21(4).

92 Impact Assessment MRV Amendment, above n. 79, p. 12
} 
following the IMO's lower transparency standards would reduce the capacity for the EU Maritime MRV to address market failures and achieve 'positive environmental impacts'. ${ }^{93}$

Perhaps most ominously, the EU has been clear that concrete reduction measures must now follow to ensure that the sector 'contributes its fair share' to the objective of the Paris Agreement on keeping climate change 'well below $2{ }^{\circ} \mathrm{C}$ ' ${ }^{94}$ To this end, Directive 2018/410 instructs the Commission to keep IMO progress 'under regular review'. ${ }^{95}$ Holding the ultimatum in place, it further notes that '[a]ction from the IMO or the Union should start from 2023 ${ }^{96}$ In 2018, the IMO did agree on an Initial Reduction Strategy, with a minimum goal of 50\% GHG reductions from shipping by 2050 , compared to $2008 .{ }^{97}$ While supportive of this strategy, the European Parliament's resolution at the UNFCCC Conference of the Parties (COP) 25 simultaneously 'urges the Commission to propose, as soon as possible, additional EU actions [...] such as the inclusion of the maritime sector in the ETS' ${ }^{98}$ Looking ahead, this thus remains a very contentious policy point.

\section{Competing Climate Change Responses: Legal Relationships Between the EU, ICAO and IMO Rules}

The previous section has illustrated a shift in the focus of the EU's 'ultimatum strategy' from the conclusion of multilateral agreements to their subsequent design, and even implementation by participating states. As policy regarding transport emissions develops on multiple fronts, we are left with concurrent measures containing different monitoring, reporting and verification standards. The longer-term scenario is potentially more concerning, with acutely diverging reduction policies for aviation and maritime emissions. As discussed in Sect. 2, the point of departure for this analysis is that unilateral measures are permitted unless there are international rules providing otherwise. However, as will be seen, it is not so straightforward to determine which rules of international law apply to the EU here, and what they precisely entail. Sections 4.1 and 4.2 will now consider the relationship between the EU measures and those of the ICAO and IMO respectively.

\footnotetext{
93 Ibid., p. 30.

94 Parliament and Council (EU) Directive 2018/410 of 14 March 2018 amending Directive 2003/87/EC to enhance cost-effective emission reductions and low-carbon investments, and Decision (EU) 2015/1814 [2018] OJ L 76/3, rec. 4.

95 Ibid.

96 Ibid.

97 IMO Initial Reduction Strategy, above n. 1.

98 EP Resolution COP 25, above n. 5, para. 75.
} 


\subsection{The Relationship Between the EU and the ICAO Measures on Aviation Emissions}

The CORSIA was adopted within the broader framework of the Chicago Convention on International Civil Aviation. This treaty constituted the ICAO, Article 37 endowing the organisation competence to adopt standards and recommended practices (SARPs). Of particular relevance in the present context is ICAO Resolution A39-3, which decides to 'implement' the CORSIA (Art. 5), and sets out the general design framework. Further operationalisation can be found in Annex 16, Volume IV of the Chicago Convention, which contains the evolving CORSIA SARPs. ${ }^{99}$

At the outset, as noted by Martinez Romera in her comprehensive study, neither the Convention's Annexes nor ICAO resolutions are strictly binding on ICAO members, as these were not originally an 'integral part' of the Convention. ${ }^{100}$ The ICAO's adoption of the 'exclusivity clause' in Resolution A40-19 would then seem to have more of a political than a legal weight for the EU, particularly as the latter is not an ICAO member. Nonetheless, the European Parliament was 'deeply concerned', 'urging' Member States to file reservations, 'so as to preserve the Union's legislative autonomy with regard to measures intended to reduce GHG emissions from the aviation sector'. ${ }^{101}$ From this statement, it is unclear whether the Parliament considers its legislative competence actually limited, or whether the use of the word 'autonomy' is intended to refer to the de facto pressures that will arise if its Member States face conflicting ICAO standards. The latter seems more likely, given the EU's position on its relationship with the Chicago Convention, discussed later in this section.

Turning to the Chicago Convention, one element that does bind the parties is the procedure in situations of non-compliance with SARPs. This can be found in Article 38 which provides that:

any State which finds it impracticable to comply in all respects with any such international standard or procedure [as adopted by the ICAO according to Article 37], or to bring its own regulations or practices into full accord with any international standard or procedure after amendment of the latter, or which deems it necessary to adopt regulations or practices differing in any particular respect from those established by an international standard, shall give immediate notification to the International Civil Aviation Organization of the differences [...] [emphasis added].

The question then arises whether the EU, while not a formal party, would be subject to Article 38 of the Chicago Convention, and on what basis this would occur. One option is through functional succession, according to which an organisation when acquiring competence from its Member States, succeeds to the relevant obligations already incumbent upon all of its Member States. There is, however, much

\footnotetext{
99 CORSIA SARPs, above n. 8.

100 Martinez Romera (2017).

101 EP Resolution COP 25, above n. 5, para. 72 (emphasis added).
} 
debate on the meaning and validity of this doctrine, with differing views in both EU and public international law. From an EU law perspective, in International Fruit Company, the CJEU in principle recognised the possibility for functional succession, accepting that the EU had succeeded to its Member States' obligations under the 1947 General Agreement on Tariffs and Trade. ${ }^{102}$ However, it set the bar for functional succession very high, and in the ATAA case, explicitly rejected such succession in relation to the Chicago Convention. ${ }^{103}$ According to the CJEU, in order for the European Union to be capable of being bound, it must have assumed, and thus had transferred to it, all the powers previously exercised by the Member States that fall within the convention in question'. ${ }^{104}$ Here, EU Member States were found to have retained rights falling within the scope of the Chicago Convention. ${ }^{105}$

This strict approach to the functional succession doctrine has been criticised in the literature as being 'too simplistic', 106 and one which 'makes little sense'. ${ }^{107}$ According to Eeckhout, the doctrine itself rests on the notion that 'a transfer of powers from the Member States to the EU also entails a transfer of the Member States' international obligations'. ${ }^{108}$ The CJEU's narrow interpretation undermines the EU's likeliness to adhere to important international treaties, ${ }^{109}$ and generally exacerbates legal fragmentation.

This critique is related to a debate also avid under public international law, on the validity of the functional succession doctrine as such. The discussion is not only relevant for succession to treaties as a whole, but in relation to discrete international obligations. On one approach, international organisations, having a 'separate legal identity', are not bound by their members' obligations, as this 'would make a mockery of their independent legal existence'. ${ }^{110}$ Accepting this, the CJEU could then be seen to have created its own sui generis approach, allowing the applicability of international agreements in its legal order for its own functional reasons, rather than as a matter of international law. ${ }^{111}$ An opposing view supported here, focuses on the functional nature of international organisations' competence. ${ }^{112}$ This competence is derived from the sovereignty of its Member States, who cannot transfer more power

\footnotetext{
102 International Fruit, above n. 28, para. 18.

103 ATAA case, above n. 27, paras. 63 and 69, referring to Case C-308/06 Intertanko and Others [2008] ECR I-4057 (hereinafter: Intertanko), para. 50.

104 Ibid., para. 63.

105 Ibid., para. 70, referring to air traffic rights and charges.

106 Ziegler (2015), p. 9.

107 Eeckhout (2001), p. 400.

108 Ibid., p. 397.

109 Ibid., p. 400.

110 Discussed by Klabbers (2017), p. 988. See for a critical perspective and literature analysis of whether functional succession can and has occurred for the EU, Uerpmann-Wittzak (2009), p. 149.

111 The author is indebted to the anonymous reviewers of this article for this consideration.

112 See, Reparation for injuries suffered in the service of the United Nations, Advisory Opinion [1949] ICJ Rep. 174, 180. See further in the context of international human rights law, Ahmed and Butler (2006), p. 791.
} 
than they have. ${ }^{113}$ As noted by Schermers and Blokker, 'an organization formed by states will be bound by the obligations to which the individual states were committed when they transferred powers to the organization'. ${ }^{114}$ Contrary to the view of the CJEU, this should not be made dependent on whether there are other competences in a broader international agreement that have not been conferred to the international organisation.

As the 1944 Chicago Convention predates the 1958 EC Treaties, it could then well be argued that the EU must exercise said competence under the same conditions as those originally in place upon its Member States. This is notably different to the existing EU law provision in Article 351 of the Treaty on the Functioning of the European Union (TFEU), that rights and obligations with third countries made before 1 January 1958 or before the date of acceding states' accession 'shall not be affected by the provisions of the Treaties'. Article 351 TFEU has namely been interpreted as an obligation to allow Member States to adhere to their agreements, not to bind the EU itself to these obligations. ${ }^{115}$ A further detailed legality assessment of the unilateral ETS with the Chicago Convention goes beyond the scope of this article. ${ }^{116}$ This is a debate that could certainly reignite should the EU decide to revert the ETS to its original scope.

Taken together, while the EU may arguably be obliged to notify ICAO of differences, it appears free to consider it 'necessary' to pursue-through its Member States-higher environmental integrity standards. This latter point was indeed relied upon by the EU in establishing its position within the ICAO in respect of the first edition of the CORSIA SARPs. ${ }^{117}$ In practice however, this is politically tenuous, and was criticised by industry as being 'extremely damaging' as 'it creates the perception that it is acceptable for ICAO Member States to depart at their discretion' from ICAO agreements. ${ }^{118}$

\subsection{The Relationship Between EU and IMO Measures on Maritime Emissions}

The IMO Data Collection Scheme for maritime emissions was adopted by resolution as an amendment to Annex VI of the MARPOL Convention. ${ }^{119}$ Contrary to the Annexes to the Chicago Convention, MARPOL Annex VI is binding upon parties. ${ }^{120}$

\footnotetext{
113 See Daugirdas (2016), p. 336, referring to this phenomenon as being 'transitively bound'. See also Ahmed and Butler (2006), p. 791.

114 Schermers and Blokker (2011), p. 996, §1574.

115 ATAA case, above n. 27, para. 61.

116 This has notably been considered in some depth by Advocate General Kokott in her Opinion to the ATAA case, above n. 27. See also, Pache (2008); and Havel and Sanchez (2014), p. 217.

117 Council Decision (EU) 2018/2027 of 29 November 2018 on the position to be taken on behalf of the European Union within the International Civil Aviation Organization in respect of the First Edition of the International Standards and Recommended Practices on Environmental Protection-Carbon Offsetting and Reduction Scheme for International Aviation (CORSIA) [2018] OJ L 325/25.

118 IATA (2019), p. 2.

119 See, Resolution MEPC.278(70), above n. 4.

120 MARPOL Annex VI gives effect to Art. 212 of the UNCLOS, which instructs states to 'adopt laws and regulations to prevent, reduce and control pollution of the marine environment from or through the
} 
For its part, the CJEU has repeatedly stressed that the EU 'is not a contracting party to the Marpol 73/78 Convention, including Annex VI, and is not bound by it'. ${ }^{121}$ From an international law perspective, one may ask similar questions regarding functional succession. Here, however, the situation is somewhat different.

To start with both the MARPOL and Annex VI are younger agreements, the latter having been added by the 1997 Protocol. ${ }^{122}$ Still, following the arguments made above, it would seem consistent that, to the extent that the EU 'progressively assumed powers previously exercised by the Member States' at the time of the 1997 Protocol, these should be exercised in line with the obligations therein. ${ }^{123}$ Yet there remains another hurdle, as two EU Member States, namely Austria and Hungary, were not party to Annex VI upon its amendment. ${ }^{124}$ This presents a doctrinal problem, as accepting functional succession would effectively impose obligations on non-contracting states without their consent, contrary to the pacta tertii principle expressed in Article 34 of the Vienna Convention on the Law of Treaties.

Fundamentally, the IMO DCS is itself an amendment to Annex VI made by another international organisation, the IMO, subsequent to the EU's acquisition and exercise of its own competence. It is then questionable whether such a later amendment would ever fall within the scope of functional succession, the rationale of which relies on the obligations existing prior to conferral of power. Accepting this, the IMO DCS must be characterised as a concurrent or competing decision, for which clear-cut rules of priority are difficult to determine. ${ }^{125}$

Yet, even in the absence of a formal hierarchy, there are arguments to be made that the EU must respect the obligations of its Member States when exercising union competences. As such exercise is an extension of its Member States' sovereignty, it seems logical that the EU must not place the former in a stranglehold with their other obligations. There is notably some recognition for this notion in the duty of sincere cooperation enshrined in Article 4(3) of the Treaty on European Union (TEU). In the case Manzi and Compagnia Naviera Orchestra, the question was raised whether the EU had violated Article 4(3)TEU and the pacta sunt servanda principle, 'on the ground that that provision of the [relevant] Directive may lead to an infringement of [MARPOL] Annex VI and thereby require Member States party to the 1997

\footnotetext{
Footnote 120 (continued)

atmosphere' (para. 1). It has been suggested that this also applies to the ICAO for aviation emissions, see further, Martinez Romera (2017).

121 Case C-537/11, Manzi and Compagnia Naviera Orchestra, EU:C:2014:19 (hereinafter: Manzi), para. 37.

122 See n. 9 above.

123 To use the terminology of the CJEU itself in Intertanko, above n. 103, para. 48.

124 The current status of the conventions can be found at: https:/www.imo.org/en/About/Conventions/ StatusOfConventions/Pages/Default.aspx (accessed 8 November 2019).

125 The issue of legal hierarchy has notably been discussed considerably in the context of the United Nations and the EU, but there the UN has a clear claim to primacy based on Art. 103 of the UN Charter. According to Schermers and Blokker (2011), p. 1005 '[s]ome decisions of international organizations may apply to other organizations because they bind the member states of those other organizations'. There does not appear to be a clear institutional instruction to this effect in the case of the EU and the IMO however.
} 
Protocol to infringe their obligations with regard to the other Contracting Parties thereto'. ${ }^{126}$ The CJEU however, declined to answer this question, finding that as the Union is not a party it had no competence to review compatibility with MARPOL Annex VI. ${ }^{127}$ According to the Court, this 'may not be circumvented by relying on the alleged infringement of the principle of cooperation in good faith laid down in the first subparagraph of Article 4(3) TEU'. ${ }^{128}$ Still, it was recognised that 'although the European Union is not bound by an international agreement, the fact that all its Member States are contracting parties to it is liable to have consequences for the interpretation of European Union law', in particular relevant secondary law. ${ }^{129}$ From an international law perspective, it is questionable whether this construction gives sufficient respect to Member States' other obligations. Such respect arguably extends beyond consistently interpreting concurrent rules to the creation of these rules themselves.

Drawing together these considerations, the EU would not seem bound by the IMO DCS, even though this amends MARPOL Annex VI, which has binding force. That being said, the EU arguably has some duty not to use its derived sovereign power to force its Member States to violate their other obligations. In the present context, there is not (yet) a strict 'conflict' of norms, as Member States can enact both sets of standards and operators can in principle comply with both. ${ }^{130}$ Still, there remains a conflict in the broader sense defined above, given the differing views on how to respond to the same problem. The existence of these dual regulatory burdens triggers important questions on the balance of regulatory competences of equal sovereign states. This is an issue for the law of state jurisdiction which will now be considered further in Sect. 5.

\section{Customary Rules on Regulatory Competence: The Law of State Jurisdiction}

Supplementing the specific rules on international transport emissions, the customary international law of state jurisdiction contains general rules on state competence to regulate the conduct and consequences of an event. ${ }^{131}$ Typically, these rules come into play when states seek to regulate conduct or circumstances occurring beyond their territory, as it is then that concurrent jurisdictional claims arise. ${ }^{132}$ The present case is no exception. For aviation, the current EU ETS covers flights between EEA aerodromes, while the EU Delegated Regulation 'supplementing' the Aviation

\footnotetext{
126 Manzi, above n. 121, para. 36.

127 Ibid., para. 41.

128 Ibid., para. 40.

129 Ibid., para. 45.

130 This is a narrow approach to 'true conflict', which 'would presume that conflict exists if it is possible for a party to two treaties to comply with one rule only by thereby failing to comply with another rule'. ILC Report on Fragmentation, above n. 29, para. 24.

131 Lowe and Staker (2010), p. 313.

132 See further, Ryngaert (2015), p. 6.
} 
Directive extends key MRV requirements to outermost regions, or dependencies and territories. ${ }^{133}$ Flights between states are considered 'international' under the CORSIA SARPs and are therefore also covered by the CORSIA. ${ }^{134}$ A potential expansion of the ETS to all flights to and from the EEA or EU would obviously exacerbate the dual regulatory burden. As regards maritime emissions, the EU Maritime MRV applies to ships on voyages to and from all EU ports. ${ }^{135}$ This covers conduct on voyages of large vessels flying all flags before and after they are in EU territory, and clearly anticipates the possibility for the EU to design a further MBM with the same geographical scope. ${ }^{136}$

Jurisdictional assertions that reach beyond territorial boundaries raise questions of 'extraterritoriality', a contested topic in legal discourse. ${ }^{137}$ In assessing the applicable jurisdictional rules, Sect. 5.1 will first consider the possible jurisdictional basis for the EU's unilateral emission reduction measures. Section 5.2 then turns to the more normative question of interest-balancing, both doctrinally within the law of state jurisdiction, and more concretely in the context of international transport emissions.

\subsection{The Jurisdictional Basis for the EU Emission Reduction Measures for International Transport}

Unilateral measures seeking to regulate extraterritorial conduct require a valid jurisdictional basis. A key voice in the debate on when this may be the case has been the CJEU itself. In the ATAA case, the CJEU assessed the permissibility of the EU Aviation Directive in its full international scope according to customary jurisdictional rules. There it found that the EU had 'unlimited jurisdiction' based on the territorial presence of the aircraft in EU aerodromes. ${ }^{138}$ However, as this author has argued elsewhere, this interpretation does not appear consistent with the theory and rationale of the law of state jurisdiction. ${ }^{139}$ The fact that aircraft are present on one end of the journey is relevant for the legality of the enforcement measures. Enforcement jurisdiction 'to ensure compliance with its laws' is namely strictly territorial. ${ }^{140}$ It is not however a sufficient basis for prescriptive jurisdiction, which pertains to 'the authority of a state to make its law applicable to particular persons or circumstances'. ${ }^{141}$ As will now be discussed, the reason for this has to do with the material protection of sovereign equality.

\footnotetext{
133 Delegated Regulation regarding ICAO MRV measures, above n. 40, Art. 1(a).

134 See n. 69. See for further, Erling (2017).

135 EU Maritime MRV, above n. 76, Art. 2.

136 See for further analysis of the issue of extraterritoriality, Dobson and Ryngaert (2017), p. 307.

137 This is particularly evident for market-entry conditions that are enforced territorially. See further e.g. Bartels (2002); Cooreman (2017); Scott (2014); Ringbom (2011); Ryngaert and Ringbom (2016).

138 ATAA case, above n. 27, para. 124.

139 Dobson and Ryngaert (2017), p. 308.

140 Report of the International Law Commission on the Work of its 58th Session (1 May-9 June and 3 July-11 August 2006), UN Doc. A/61/10, Annex E (hereinafter: ILC Report on Extraterritorial Jurisdiction), p. 518.

141 International Bar Association (2009), p. 7.
} 
Essentially, the operation of the EU's measures is de facto dependent on conduct or circumstances abroad. Such measures give rise to a 'potential interference' with the regulatory autonomy, and thus the sovereignty, of other states. ${ }^{142}$ Notably, the interests of private actors are considered here as an extension of the regulatory choices of different states. Thus, where a home state has chosen not to burden its producers with certain environmental regulations, foreign state measures imposing costs on these actors raise issues of jurisdiction. Such 'potential interference' needs justification based on more than partial territorial presence, as this would otherwise disregard a measure's very real impact on activities beyond the regulator's territory. Recognition for the effects of one jurisdictional assertion on the regulatory space left for others, aligns with the function of jurisdiction rules, namely to assign and apportion regulatory claims. ${ }^{143}$ Measures whose operation is de facto dependent on foreign conduct or circumstances are therefore characterised here as having an 'extraterritorial element', making them measures of interest under the law of state jurisdiction.

There are several bases which may support assertions of prescriptive jurisdiction with an 'extraterritorial element' under customary law. In addition to territory, these are nationality, effects, protection, and universality. ${ }^{144}$ These bases may notably be applied individually or together, the relevant legal threshold being whether a regulator can demonstrate a 'substantial connection' to the subject matter in question. ${ }^{145}$ To start with, the nationality principle provides a basis of jurisdiction over nationals-including ships flying a flag of, or aircraft registered to-a particular state. ${ }^{146}$ In addition, according to the effects-doctrine, a state may regulate 'conduct outside its territory that has or is intended to have substantial effect within its territory'. ${ }^{147}$ Related to this is the protection principle, granting jurisdiction over conduct that threatens vital national interests. ${ }^{148}$ These last two principles are based on states' sovereign rights to respond to threats and protect their territory. Finally, the universality principle provides a basis for jurisdiction over conduct that threatens fundamental values of the international community, in the absence of any specific link to the regulating state. ${ }^{149}$ This principle has evolved in the field of criminal law, with state practice to date largely focusing on grave crimes.

In the realities of our complex, globalised world, the jurisdictional bases cannot always be applied in a clear-cut manner. Today, it is therefore generally-accepted that to validly assert prescriptive jurisdiction, states must demonstrate a 'genuine'

\footnotetext{
142 See for the use of 'interference' as an indicator that jurisdictional issues arise, e.g. ILC Report on Extraterritorial Jurisdiction, above n. 140, p. 518.

143 See further on jurisdiction 'as a concern of international law', Ryngaert (2015), pp. 5-6.

144 See for a detailed analysis, ibid.

145 See further e.g., ILC Report on Extraterritorial Jurisdiction, above n. 140, p. 521.

146 Ibid., p. 522.

147 Ibid., see also, US Fourth Restatement, above n. 11, §409.

148 See further, Harvard Draft Convention on Jurisdiction with Respect to Crime (1935).

149 O'Keefe (2004), p. 745: '[i]t would seem sufficiently well agreed that universal jurisdiction amounts to the assertion of jurisdiction to prescribe in the absence of any other accepted jurisdictional nexus at the time of the relevant conduct'.
} 
or 'substantial connection' to the regulated subject matter. ${ }^{150}$ This may be made up of one or more of the abovementioned bases. Yet the application of the 'substantial connection' requirement in the relatively newer context of climate change remains quite unclear. Some support can be found in the literature for such expansive EU measures. Considering the issue more generally, Ringbom for example notes that the principles of jurisdiction 'seem to leave some room for port States to apply requirements which relate to activities beyond their maritime zones' ${ }^{151} \mathrm{Scott}$ considers such measures an exercise of 'territorial extension', which have received measured acceptance from both the CJEU or the Appellate Body of the World Trade Organisation. ${ }^{152}$

A detailed analysis of the operationalisation of substantial connection requirement goes beyond the scope of this article, and has been the subject of extensive debate elsewhere. ${ }^{153}$ In short, it is submitted by this author that a state may have a 'substantial connection', when it can demonstrate, based on consistent scientific evidence, that the subject matter regulated measurably contributes to an increase in the risk of reasonably foreseeable grave harm. ${ }^{154}$ This aligns with the preventative rationale of the effects and protection bases, while also infusing elements of precaution from international environmental law. Such a claim is arguably reinforced when the measure aims to protect a community interest of 'common concern', such as climate change. ${ }^{155}$ In the view of this author, the EU can demonstrate such a substantial connection to the international maritime and aviation transport activities, which contribute a substantial proportion of total global emissions cumulatively resulting in anthropogenic climate change.

\subsection{Consideration of Other Interests as a Condition on Unilateral Jurisdiction?}

The classical principles analysed above all focus on the interests of the regulating actor. Clearly, there is a myriad of other interests also engaged when the EU refuses to align with multilateral measures regulating emissions from international transport. This gives rise to tensions with the principle of sovereign equality. As authoritatively explained by Meessen, in a jurisdictional context this principle entails the right of states 'to pursue the regulatory goals it has decided to adopt'. ${ }^{156}$ Notably, tensions with this principle may arise even in the absence of competing legislation, as the choice not to regulate also falls within the regulatory autonomy afforded by sovereign equality.

\footnotetext{
150 See e.g. Crawford (2012), p. 447; Kamminga (2011), para. 9; US Fourth Restatement, above n. 11.

151 Ringbom (2011), p. 632.

152 Scott (2014), p. 113.

153 This has been the subject of this author's doctoral dissertation, Dobson (2018a). For discussion in the context of EU aviation measures see e.g. Scott (2014) and Havel and Mulligan (2012). For discussion on the EU Maritime MRV specifically see e.g., Kopela (2016); Dobson and Ryngaert (2017).

154 Dobson (2018b).

155 See for an analysis of jurisdiction and climate change as a 'common concern', Cottier et al. (2014).

156 Meessen (1984), p. 804.
} 
In the case of a competing multilateral measure the problem is clearly exacerbated, as it is not one sovereign interest against the other, but one against many. In practice however, it is a rather artificial exercise to seek to balance competing claims based on the number of sovereign states supporting a measure. Indeed, in all multilateral settings real power imbalances will inevitably shape the final agreements reached, meaning that an international agreement is not the product of perfect sovereign equality. ${ }^{157}$ For the EU, while its legislation formally represents the interests of all of its Member States, its law-making intuitions, in particular the Commission, have far-reaching autonomy. Their decisions are then by no means a negotiated compromise reached by its Member States.

The question remains therefore, whether and how states must consider the legitimate interests of others when exercising jurisdiction with an extraterritorial element. In the literature, this is referred to as a matter of 'reasonableness' or 'interest-balancing', the terminology largely stemming from the 1987 Restatement (Third) of US Foreign Relations Law (US Third Restatement). ${ }^{158}$ For a long time, this was one of the most comprehensive and authoritative documents dealing explicitly with jurisdictional interest-balancing beyond the field of private international law. Of particular importance is $\$ 403$ which precludes states from exercising jurisdiction, despite the existence of a valid basis, when this would be 'unreasonable'. Importantly this 'rule of reason' was considered by the drafters to reflect customary international law. ${ }^{159}$ According to $\S 403(2)$ the unreasonableness of an act was to be determined 'by evaluating all relevant factors' including:

(c) the character of the activity to be regulated, the importance of regulation to the regulating state, the extent to which other states regulate such activities, and the degree to which the desirability of such regulation is generally accepted.

(d) the existence of justified expectations that might be protected or hurt by the regulation;

$[\ldots]$

(g) the extent to which another state may have an interest in regulating the activity; and

(h) the likelihood of conflict with regulation by another state.

In terms of concrete application, this very open interest-balancing test may point in several directions at once. Indeed, the test was subsequently rejected by US courts as being unworkable in practice, particularly when applied by domestic courts. ${ }^{160}$

\footnotetext{
157 See further in an EU context, 'policy-forging unilateralism', Boisson de Chazournez (2000).

158 Restatement (Third) of the Foreign Relations Law of the United States (Am Law Inst 1987) (hereinafter: US Third Restatement). See also Ryngaert (2015), p. 152.

${ }^{159}$ US Third Restatement, above n. 158, $\$ 403$, comment a.

160 Laker Airways 731 F.2d 909, 950-952 (D.C. Cir. 1984).
} 
Published in 2018, the US Fourth Restatement confirms a lack of state practice and opinio juris to support §403's rule of reason as a requirement of custom. ${ }^{161}$ In fact, according to the Fourth Restatement, the only element of 'reasonableness' required by international law is that of a 'genuine connection' to the regulated subject matter. ${ }^{162}$ Beyond that, the Reporters' Notes consider that 'states often seek to reduce conflicts of prescriptive jurisdiction through various rules of domestic law that are often motivated by international comity but are not required by international law'. ${ }^{163}$ We thus see a shift in the characterisation of reasonableness from one of custom to one of voluntary comity.

In the view of this author, while the emphasis on the requirements for the formation of custom is understandable, the characterisation of jurisdictional self-restraint as purely voluntary goes too far in the opposite direction. Following this approach would namely mean that international law contains no binding protections for the sovereign interests of states whose regulatory autonomy is affected by prima facie valid jurisdictional assertions. This again does not seem to give sufficient attention to the principle of sovereign equality. It also risks overlooking the related principles of non-intervention and non-interference, which serve to realise sovereign equality. ${ }^{164}$ While the precise operationalization of these principles is unclear, they certainly apply to the exercise of legislative jurisdiction.

It is argued that, rather than manifesting as defined limitations, these principles serve to inform national comity doctrines such as 'reasonableness in interpretation' and the 'presumption against extraterritoriality'. ${ }^{165}$ The blending of law and comity is further catalysed by the widely-accepted doctrine of consistent interpretation with international law. ${ }^{166}$ As such, state practice demonstrating jurisdiction self-restraint is necessarily a reflection of both custom and comity. Applied to the present case, it seems that these principles of sovereign equality, non-interference and non-intervention support a duty of the EU to align its measures with those of the ICAO and IMO.

Importantly however, the forgoing discussion is premised on the assumption that the EU and multilateral measures are real alternatives to each other. In reality this is clearly not the case. For shipping, in the EU's view, the IMO DCS lacks the transparency, reliability and completeness of information that its Maritime MRV offers. Based on its impact assessment, the EU considers its level of protection necessary to achieve its projected $2 \%$ reduction in GHG emissions compared to business as usual standards. ${ }^{167}$ For aviation, it is clear that a carbon-offsetting scheme simply does not

\footnotetext{
161 US Fourth Restatement, above n. 11, R. §407, Reporters' Note 3.

162 Ibid., $\$ 407$, Reporters' Note 6. See further discussion on this by William Dodge, one of the drafters of Fourth Restatement section on Jurisdiction, Dodge (2019).

163 US Fourth Restatement, above n. 11, §407, Reporters' Note 6.

164 Kokott (2007), para. 1. Non-interference for example being raised in a jurisdictional context in $A$ Ahlstrom Osakeyhtio v. Commission [1988] ECR 5193. A clear example of the consideration of the nonintervention principle is the Canadian case $R v$. Hape 2007 SCC 26.

165 Dobson (2019), p. 27. These comity principles can be found in the US Fourth Restatement, above n. $11, \S 405$ and $\$ 404$ respectively.

166 Tzanakopoulos (2012).

167 Impact Assessment MRV Amendment, above n. 79, p. 12.
} 
provide the same level of protection as a cap-and-trade scheme which puts a ceiling on emissions. ${ }^{168}$ The latter was considered by the ICAO, but somewhat unsurprisingly, given the pressure from the aviation industry, ultimately was not chosen. ${ }^{169}$ Indeed, the International Coalition for Sustainable Aviation went so far as to argue that replacement of the ETS with the CORSIA would, given the latter's environmental weakness, 'constitute a breach of Europe's obligations under the Paris Agreement'. ${ }^{170}$

This raises questions as to how the duty to respect regulatory autonomy relates to the obligations in the multilateral climate agreements. It is clear that the EU is bound by the UNFCCC and the Paris Agreement to which it is a party. ${ }^{171}$ Yet as discussed, silently continuing the approach of Article 2(2) of the Kyoto Protocol, the Paris Agreement does not explicitly include international aviation and maritime transport emissions. There are compelling arguments to be made that the UNFCCC's recognition of climate change as a 'common concern of humankind' and its overarching objective of preventing 'dangerous' climate change imply a (collective) obligation for states to adopt sufficiently ambitious reduction targets. ${ }^{172}$ This would hold irrespective of the voluntary element in the setting of National Determined Contributions (NDCs). Arguably then, the aviation and maritime transport sectors, as sizeable contributors to global warming, would need to make a meaningful contribution to the required mitigation targets. This appears reflected in the EU's position that 'all sectors of the economy must contribute' to achieving its $40 \%$ reduction commitment under the Paris Agreement. ${ }^{173}$

For their part, it is doubtful whether the IMO and ICAO consider that the climate change regime contains a binding goal for them. The IMO has stressed that 'the Paris Agreement does not include international shipping'. ${ }^{174}$ Its Initial Reduction Strategy notes quite vaguely that it is 'aimed at enhancing IMO's contribution to global efforts by addressing GHG emissions from international shipping' including 'the Paris Agreement and its goals' ${ }^{175}$ In similarly ambiguous wording, the ICAO notes that "work is being undertaken to explore a long-term global aspirational goal for international aviation in light of the $2{ }^{\circ} \mathrm{C}$ and $1.5{ }^{\circ} \mathrm{C}$ temperature goals of the Paris Agreement'. ${ }^{176}$ Resolution A40-18 explicitly denies 'any attribution of specific

\footnotetext{
168 See for analysis of CORSIA's effectiveness, Carbon Brief (2019).

169 See further on the noted effects on industry pressure, Erling (2017), pp. 4, 5; Hermwille (2016).

170 Emphasis added. International Coalition for Sustainable Aviation, 'Letter: CORSIA \& European climate ambition on aviation' (12 September 2018), available at: https://carbonmarketwatch.org/publicatio ns/letter-corsia-european-climate-ambition-on-aviation/ (accessed 16 September 2019).

171 This is also recognised under EU law in the TFEU, above n. 15, Art. 216(2).

172 UNFCCC above n. 12, Art. 2 and rec. 1. On the possible obligations posed under the climate change regime see e.g. Zahar (2019), p. 3; Voigt (2008), p. 4; Peel (2017), p. 1019.

173 This includes maritime emissions, which while not currently included 'are a concern that needs to be tackled both globally and domestically, and included in the National Determined Contributions' (Impact Assessment MRV Amendment, above n. 79, p. 6).

174 See, https://www.imo.org/en/MediaCentre/PressBriefings/Pages/06GHGinitialstrategy.aspx (accessed 6 December 2019).

175 IMO Initial Reduction Strategy, above n. 1, p. 4.

176 Emphasis added. ICAO Resolution A40-18, 'Consolidated statement of continuing ICAO policies and practices related to environmental protection-Climate change' (adopted 40th Session of the ICAO Assembly, 24 September-4 October 2019), rec. 10.
} 
obligations to individual States', in the achievement of 'a collective medium-term global aspirational goal of keeping the global net carbon emissions from international aviation from 2020 at the same level'. ${ }^{177}$ This issue is sure to gain attention in the future.

The lack of defined ambition of the ICAO and IMO aggravates the interest-balancing dilemma in the law of state jurisdiction. While the principle of sovereign equality requires states to respect each other's regulatory space, it is questionable whether autonomy necessarily prevails when it hampers the achievement of the near-universally accepted objective of the climate change regime. This is to say nothing of the far broader ethical implications that formalistic respect for sovereign equality may have for the recognition of the interests of future generations and of vulnerable states with less bargaining power. We are thus left with important normative dilemmas for the further crystallisation of international climate change rights and obligations.

\section{Conclusion}

With the 'emission gap' still gaping, there is an urgent need for regulatory responses to the increasing emissions from international transport. While the emergence of multilateral rules is to be welcomed, doubts remain as to the adequacy of their level of ambition. As a global actor with economic clout, the EU is in a unique position to unilaterally exercise pressure on ICAO and IMO policy. Questions arise, however, as to the extent to which the development of these competing multilateral responses to climate change may limit the EU's regulatory freedom. This issue is steeped in a myriad of disagreements, which hinge on varying conceptions of the relationship between the EU and the international legal order. The present contribution has sought to navigate these debates from the perspective of international law.

In the context of aviation, it could be argued that the EU has functionally succeeded to certain obligations under the Chicago Convention, including Article 38 on non-compliance with ICAO SARPs. Still, as the CORSIA is not binding and may be deviated from if 'necessary', the EU retains a degree of regulatory freedom. The ICAO's 2019 'exclusivity clause' would not seem to alter this relationship, though it may impose de facto limitations on EU regulatory autonomy. For the regulation of shipping emissions under MARPOL Annex VI, functional succession does not seem plausible. While binding on parties, Annex VI is a younger agreement which was amended to include the multilateral scheme after the EU had been conferred regulatory competence in the same field. Despite the lack of hard limits, it is nonetheless arguable that the EU has an indirect duty to respect the obligations of its Member States, derived from the functional nature of its competences. While the EU principle of sincere cooperation supports some alignment through consistent interpretation, under international law this should arguably extend to policy design.

177 Ibid., para. 6. 
In light of the looming regulatory burdens, more general questions of state jurisdiction have also been considered. It is argued that the EU may well be able to demonstrate a valid jurisdictional basis for its expansive measures. This must, however, be exercised with sufficient respect for the sovereign equality of other states. Operationalising concrete jurisdictional limitations remains, however, complex. Even assuming that sovereign equality and non-interference support a duty for the EU to respect the multilateral responses from the ICAO and the IMO, this may well undermine the UNFCCC and Paris Agreement aim of preventing 'dangerous' climate change. Between these competing norms and interests, the EU then remains both a hero and a hegemon. More fundamental questions remain for the design of the international legal system as a whole. As the legal relationships continue to evolve, it is to be hoped that necessity will be the 'mother of invention'. ${ }^{178}$

Acknowledgements The author would like to thank Megan Robertson, Cedric Ryngaert and the anonymous reviewers for their valuable comments.

Open Access This article is licensed under a Creative Commons Attribution 4.0 International License, which permits use, sharing, adaptation, distribution and reproduction in any medium or format, as long as you give appropriate credit to the original author(s) and the source, provide a link to the Creative Commons licence, and indicate if changes were made. The images or other third party material in this article are included in the article's Creative Commons licence, unless indicated otherwise in a credit line to the material. If material is not included in the article's Creative Commons licence and your intended use is not permitted by statutory regulation or exceeds the permitted use, you will need to obtain permission directly from the copyright holder. To view a copy of this licence, visit http://creativecommons.org/licen ses/by/4.0/.

\section{References}

Ahmed T, Butler I (2006) The European Union and human rights: an international law perspective. EJIL 17:771-801

Bartels L (2002) Article XX of GATT and the problem of extraterritorial jurisdiction- the case of trade measures for the protection of human rights. JWT 36:353-378

Bäuerle T (2012) Integrating shipping into the EU Emissions Trading Scheme? In: Koch HJ, König D, Sanden J (eds) Climate change and environmental hazards related to shipping: an international legal framework. Brill, Leiden, pp 109-119

Bodansky D (2000) What's so bad about unilateral action to protect the environment? EJIL 11(2):339-347

Boisson de Chazournes L (2000) Unilateralism and environmental protection: issues of perception and reality of issues. EJIL 11:315-338

Boserup E (1981) Population and technological change: a study of long-term trends. University of Chicago Press, Chicago

Cooreman B (2017) Global environmental protection through trade: a systematic approach to extraterritoriality. Edward Elgar, Cheltenham

Cottier T et al (2014) The principle of common concern and climate change. AVR 52:293-324

Carbon Brief (2018) Analysis: aviation could consume a quarter of 1.5C carbon budget by 2050. https:// www.carbonbrief.org/aviation-consume-quarter-carbon-budget. Accessed 17 September 2019

Carbon Brief (2019) Corsia: the UN's plan to 'offset' growth in aviation emissions after 2020. https:// www.carbonbrief.org/corsia-un-plan-to-offset-growth-in-aviation-emissions-after-2020. Accessed 17 September 2019

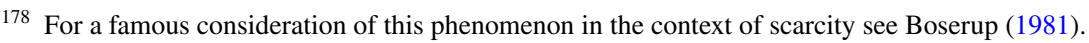


Crawford J (2012) Brownlie's principles of public international Law, 8th edn. Oxford University Press, Oxford

Daugirdas K (2016) How and why international law binds international organizations. Harv Int Law J 57(2):325-381

Dobson NL (2018a) Extraterritoriality in international law: the case of EU climate protection. PhD Thesis, Utrecht University

Dobson NL (2018) Exploring the crystallization of 'climate change jurisdiction': a role for precaution? Clim Law 8:207-228

Dobson N (2019) Reflections on 'reasonableness' in the Restatement (Fourth) of US Foreign Relations Law. QIL 62:19-34

Dobson N, Ryngaert C (2017) Provocative climate protection: EU 'extraterritorial' regulation of maritime emissions. ICLQ 66:295-333

Dodge WS (2019) Jurisdictional reasonableness under customary international law: the approach of the Restatement (Fourth) of US Foreign Relations Law. QIL 62:5-18

Dupuy PM (2000) The place and role of unilateralism in contemporary international law. EJIL 11:19-29

Eeckhout P (2011) EU external relations law, 2nd edn. Oxford University Press, Oxford

Erling U (2017) International aviation emissions under International Civil Aviation Organization's global market based measure: ready for offsetting? Air Space Law 42:1-12

Erling U (2018) How to reconcile the European Union Emissions Trading System (EU ETS) for aviation with the Carbon Offsetting and Reduction Scheme for International Aviation (CORSIA)? Air Space Law 43:371-386

Hakimi M (2014) Unfriendly unilateralism. Harv Int Law J 55:105-150

Havel B, Mulligan JQ (2012) Flying too high? Extraterritoriality and the EU Emissions Trading Scheme: the Air Transport Association of America judgment. https://eutopialaw.com/2012/02/02/958/. Accessed 2 May 2014

Havel B, Sanchez G (2014) The principles and practice of international aviation law. Cambridge University Press, Cambridge

Harvard Draft Convention on Jurisdiction with Respect to Crime (1935) Article 7. Protection-security of the state. AJIL Suppl Res Int Law 29:543-561

Hermwille L (2016) Offsetting for international aviation: the state of play of market-based measures under ICAO. https://www.researchgate.net/publication/301342727. Accessed 3 Sep 2019

IATA (2019) International Air Transport Association: comments on the Commission's draft Delegated Regulation on reporting measures to implement CORSIA. https://ec.europa.eu/info/law/better-regul ation/initiatives/ares-2018-6069911/feedback/F15893_en?p_id=336799. Accessed 15 July 2019

International Bar Association (2009) Report of the taskforce on extraterritorial jurisdiction. https://tinyu rl.com/taskforce-etj-pdf. Accessed 21 April 2020

Jennings R, Watts A (1992) Oppenheim's international law, 9th edn. Oxford University Press, Oxford

Kamminga M (2011) Extraterritoriality. In: Wolfrum R (ed) Max Planck encyclopaedia of public international law, online edn. Oxford University Press, Oxford

Klabbers J (2017) The sources of international organizations law. In: d'Aspremont J, Besson S (eds) The Oxford handbook of the sources of international Law. Oxford University Press, Oxford, pp 987-1006

Kokott J (2007) States, sovereign equality. In: Wolfrum R (ed) Max Planck encyclopaedia of public international law, online edn. Oxford University Press, Oxford

Kopela S (2016) Port-state jurisdiction, extraterritoriality, and the protection of global commons. Ocean Dev Int Law 47:89-130

Kulovesi K (2011) Make your own special song, even if nobody else sings along: international aviation emissions and the EU Emissions Trading Scheme. Clim Law 2:535-558

Lowe V, Staker C (2010) Jurisdiction. In: Evans M (ed) International law. Oxford University Press, Oxford, pp 313-339

Martinez Romera B (2016) The Paris Agreement and the regulation of international bunker fuels. RECIEL 25:215-227

Martinez Romera B (2017) Regime interaction and climate change: the case of international aviation. Routledge, Abingdon

Meessen K (1984) Antitrust jurisdiction under customary international law. AJIL 78:783-810

Morgan S (2019) EU emissions scheme excluded from UN aviation offsets. Climate Change News, 7 October 2019. https://www.climatechangenews.com/2019/10/07/eu-emissions-scheme-excludedaviation-carbon-offsets/. Accessed 6 Dec 2019 
Nollkaemper A (2011) Unilateralism/multilateralism. In: Wolfrum R (ed) Max Planck encyclopaedia of public international law, online edn. Oxford University Press, Oxford

O'Keefe R (2004) Universal jurisdiction clarifying the basic concept. JICJ 2:735-745

Pache E (2008) On the compatibility with international legal provisions of including greenhouse gas emissions from international aviation in the EU emission allowance trading scheme as a result of the proposed changes to the EU Emission Allowance Trading Directive. Legal opinion commissioned by the Federal Ministry for the Environment, Nature Conservation and Nuclear Safety, Würzburg

Peel (2017) Climate change. In: Nollkaemper A, Plakokefalos I (eds) The practice of shared responsibility in international law. Cambridge University Press, Cambridge, pp 1009-1050

Reinisch A (2017) Sources of international organizations' law: why custom and general principles are crucial. In: d'Aspremont J, Besson S (eds) The Oxford handbook of the sources of international law. Oxford University Press, Oxford, pp 1007-1024

Ringbom H (2011) Global problem-regional solution? International law reflections on an EU CO2 emissions trading scheme for ships. IJMCL 26:613-641

Rothenberg F (2019) CORSIA exclusivity clause-potential EU ETS implication. ICIS, 8 October 2019. https://www.icis.com/explore/resources/news/2019/10/11/10427666/corsia-exclusivity-clause-poten tial-eu-ets-implications. Accessed 21 Apr 2020

Ryngaert C (2015) Jurisdiction in international law. Oxford University Press, Oxford

Ryngaert C, Ringbom H (2016) Introduction: port state jurisdiction: challenges and potential. IJMCL 31:379-394

Sands P (2000) Unilateralism, values, and international law. EJIL 11(2):291-302

Schermers H, Blokker N (2011) International institutional law: unity within diversity. Brill, Leiden

Scott J (2014) Extraterritoriality and territorial extension in EU law. AJIL 62:87-123

Scott J, Rajamani L (2012) EU climate change unilateralism. EJIL 23:469-740

Tzanakopoulos A (2012) Principles on the engagement of domestic courts with international law. International Law Association preliminary report

Uerpmann-Wittzak R (2009) The constitutional role of international law. In: von Bogdandy A, Bast J (eds) Principles of European constitutional law. Hart Publishing, Oxford, pp 131-168

van Asselt H (2007) Dealing with the fragmentation of global climate governance legal and political approaches in interplay management. Global Governance working paper 30

van Velzen A (2018) CORSIA, EU ETS and the EU2030 aviation emissions target. Report prepared for Transport and Environment, report nr: 18-13, September 2018. https:/www.transportenvironment .org/sites/te/files/publications/2018_09_Study_CORSIA_EU_ETS_and_EU2030_aviation_emiss ions_target_Final.pdf. Accessed 21 Apr 2020

Voigt C (2008) State responsibility for climate change damages. Nordic J Int Law 77(1):1-22

Wessel R, Odermatt J (2018) Research handbook on the EU's engagement with international organisations. Edward Elgar Publishing, Cheltenham

Zahar A (2019) Collective obligation and individual ambition in the Paris Agreement TEL 1-24 (first view). https://doi.org/10.1017/S2047102519000281

Ziegler K (2015) The relationship between EU law and international law. University of Leicester School of Law research paper no. 15-04

Publisher's Note Springer Nature remains neutral with regard to jurisdictional claims in published maps and institutional affiliations. 